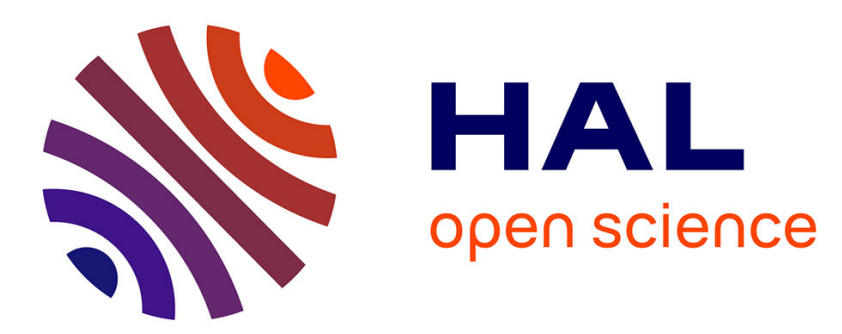

\title{
Asymmetric Synthesis of Highly Functionalized Tetrahydrothiophenes by Organocatalytic Domino Reactions
}

\author{
Sven Brandau, Eddy Maerten, Karl Anker Jørgensen
}

\section{To cite this version:}

Sven Brandau, Eddy Maerten, Karl Anker Jørgensen. Asymmetric Synthesis of Highly Functionalized Tetrahydrothiophenes by Organocatalytic Domino Reactions. Journal of the American Chemical Society, 2006, 128 (46), pp.14986 - 14991. 10.1021/ja065507+ . hal-03412829

\author{
HAL Id: hal-03412829 \\ https://hal.science/hal-03412829
}

Submitted on 3 Nov 2021

HAL is a multi-disciplinary open access archive for the deposit and dissemination of scientific research documents, whether they are published or not. The documents may come from teaching and research institutions in France or abroad, or from public or private research centers.
L'archive ouverte pluridisciplinaire HAL, est destinée au dépôt et à la diffusion de documents scientifiques de niveau recherche, publiés ou non, émanant des établissements d'enseignement et de recherche français ou étrangers, des laboratoires publics ou privés. 


\title{
Asymmetric Synthesis of Highly Functionalized Tetrahydrothiophenes by Organocatalytic Domino Reactions
}

\author{
Sven Brandau, Eddy Maerten and Karl Anker Jørgensen* \\ Danish National Research Foundation, Center for Catalysis, Department of Chemistry, Aarhus \\ University, DK-8000 Aarhus C, Denmark \\ E-mail:kaj@chem.au.dk
}

RECEIVED DATE (to be automatically inserted after your manuscript is accepted if required according to the journal that you are submitting your paper to)

A simple approach for the formation of optically active highly functionalized tetrahydrothiophenes, which might have importance in biochemistry, pharmaceutical- and nanoscience is presented. The development of new organocatalytic Michael-aldol domino reactions is outlined and with the appropriate choice of additives it is possible to control the regioselectivity of these domino reactions yielding diastereomerically pure (tetrahydrothiophen-2-yl)phenyl methanones or tetrahydrothiophene carbaldehydes in good yields and with excellent enantioselectivities up to $96 \%$ ee. The sterochemical outcome of these reactions is investigated and the mechanism of these organocatalytic domino processes is presented.

\section{Introduction}

Substituted tetrahydrothiophenes and optically active tetrahydrothiophenes are endowed with a large spectrum of biological activities, ranging from the essential coenzyme biotin, ${ }^{1}$ inhibitor of copper amine 
oxidases, ${ }^{2}$ antioxidant activities, ${ }^{3}$ leukotriene antagonism $^{4}$ or plant growth regulations. ${ }^{5}$ Tetrahydrothiophenes have been also used as building block for new chiral ligands in asymmetric catalysis $^{6}$ and in natural product synthesis. ${ }^{7}$ In addition, the adsorption and the properties of the related achiral, aromatic thiophenes on gold surfaces are well known, ${ }^{8}$ as their benefit for the synthesis of gold nanoparticles. ${ }^{9}$ More recently chiral sulfur compounds have also shown new and interesting properties when adsorbed to $\mathrm{Au}(110)$ surfaces. ${ }^{10}$ The investigations of chiral tetrahydrothiophenes in these research areas are just in the beginning and the influence of functionalized chiral tetrahydrothiophenes will probably provide new advantages and possibilities in these fields. Despite their high benefits in numerous applications, very few examples for an asymmetric synthesis have been developed yet. ${ }^{11}$

Asymmetric domino reactions have become a powerful tool for the synthetic chemist building up efficient complex cyclic and acyclic molecules in an easy way. ${ }^{12}$ They can form multiple stereogenic centers and fulfill in an exemplary manner one demand of modern organic synthesis, namely minimizing the number of manual operations and purifications in a synthetic sequence. ${ }^{13}$ However, during the past few years the field of asymmetric domino reactions has been dominated by metal catalysis, ${ }^{14}$ and only few examples have been published using organocatalysis. ${ }^{15}$ Organocatalysis is usually a non-toxic, metal-free and selective powerful approach for the preparation of important optically active building blocks, therefore the field of organocatalysis is a rapidly progressing area with a large number of new asymmetric reactions. ${ }^{16,17}$

Here we report the development of a new organocatalytic Michael-aldol domino reaction for the synthesis of diastereo- and enantiomerically pure tetrahydrothiophenes, building up highly functionalized tetrahydrothiophenes with three stereocenters in one step. We will present how the regioselectivity of the reaction can be controlled leading to the formation of different tetrahydrothiophenes, namely tetrahydrothiophene carbaldehydes $\mathbf{1}$, or (tetrahydrothiophen-2-yl)phenyl methanones 2, by the appropriate choice of simple additives to the organocatalytic system (Scheme 1). The common intermediate $\mathbf{3}$ for both tetrahydrothiophenes is synthesized by the first reaction in this 
domino reaction, a Michael addition of a nucleophilic thiol $\mathbf{5}$ to different aliphatic $\alpha, \beta$-unsaturated aldehydes 4 .

Scheme 1. Domino Reactions to Chiral Tetrahydrothiophenes.

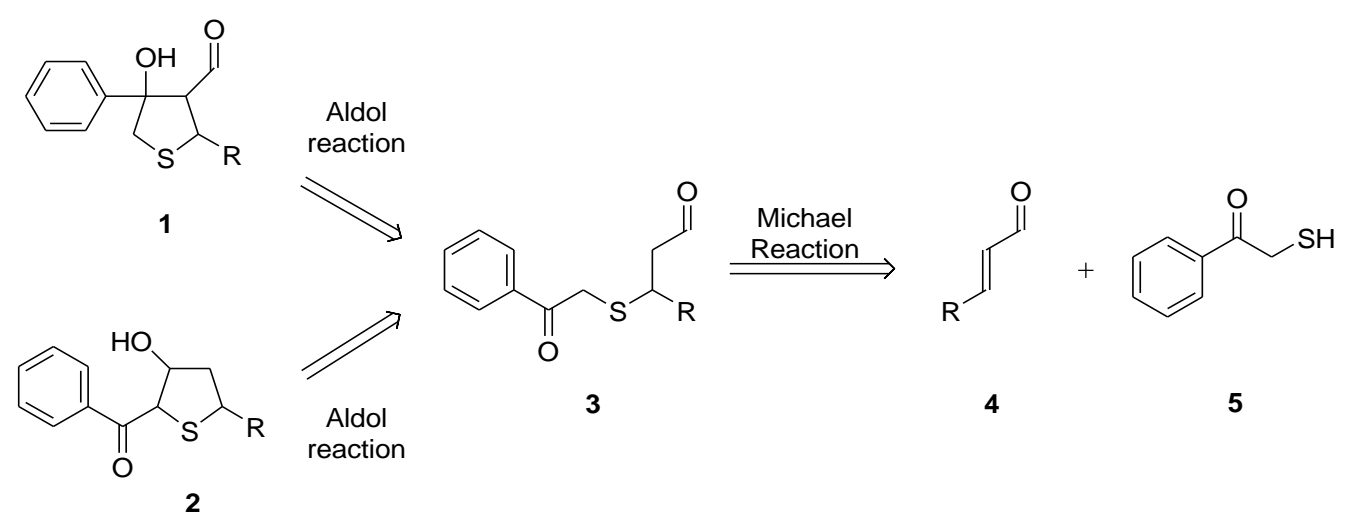

\section{Results and Discussion}

Acid-Catalyzed Domino Reactions. The organocatalytic Michael-aldol domino reaction of thiol 5 with different aliphatic $\alpha, \beta$-unsaturated aldehydes 4 was first investigated under acidic conditions. The enantioselective formation of tetrahydrothiophene carbaldehydes 1 was initially developed by reaction of (E)-4-methylpent-2-enal 4a and 2-mercapto-1-phenylethanone 5 in different solvents in the presence of the L-proline derivative $(S)$-2-[bis(3,5-bistrifluoromethylphenyl)trimethylsilanyloxymethyl]-pyrrolidine $(S)-6^{16}$ as the catalyst (Table 1$)$.

Table 1. Solvent Screening for the Domino Reaction between (E)-4-Methylpent-2-enal 4a and 2Mercapto-1-phenylethanone 5. ${ }^{a}$
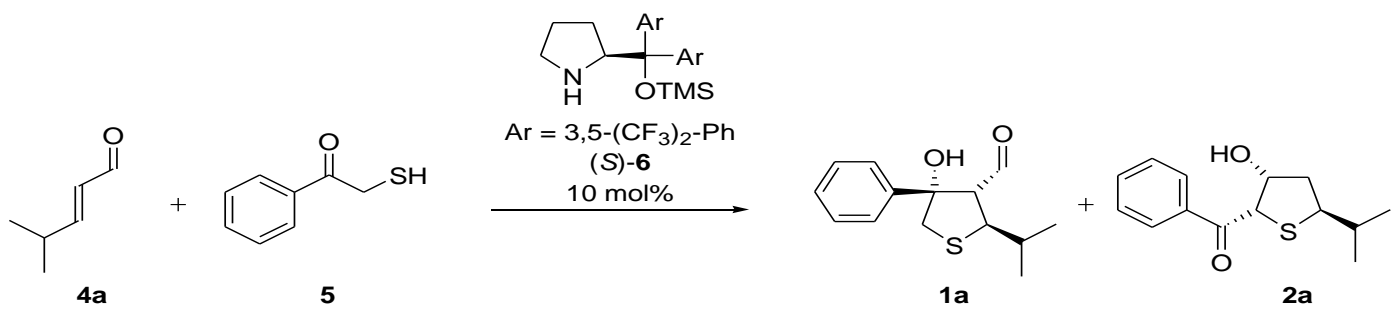


\begin{tabular}{|c|c|c|c|c|c|c|}
\hline entry & additive & solvent & $\begin{array}{l}\text { yield 1a } \\
\qquad(\%)^{b}\end{array}$ & $\begin{array}{l}\text { ee } \\
(\%)^{c}\end{array}$ & $\begin{array}{l}\text { yield 2a } \\
\left(_{(\%)^{b}}\right.\end{array}$ & $\begin{array}{c}\text { ee } \\
(\%)^{d}\end{array}$ \\
\hline $1^{e}$ & - & toluene & 40 & 92 & - & - \\
\hline $2^{f}$ & $\mathrm{PhCO}_{2} \mathrm{H}$ & toluene & 56 & 94 & - & - \\
\hline 3 & $\mathrm{PhCO}_{2} \mathrm{H}$ & $o$-xylene & 54 & 93 & - & - \\
\hline 4 & $\mathrm{PhCO}_{2} \mathrm{H}$ & benzene & 57 & 95 & - & - \\
\hline 5 & $\mathrm{PhCO}_{2} \mathrm{H}$ & $n$-pentane & 63 & 92 & - & - \\
\hline 6 & $\mathrm{PhCO}_{2} \mathrm{H}$ & $\mathrm{CH}_{2} \mathrm{Cl}_{2}$ & 9 & 76 & - & - \\
\hline 7 & $\mathrm{PhCO}_{2} \mathrm{H}$ & THF & 30 & 10 & - & - \\
\hline 8 & $\mathrm{PhCO}_{2} \mathrm{H}$ & DCE & 17 & 80 & - & - \\
\hline 9 & $\mathrm{PhCO}_{2} \mathrm{H}$ & $\mathrm{Et}_{2} \mathrm{O}$ & 24 & 60 & - & - \\
\hline 10 & $\mathrm{PhCO}_{2} \mathrm{H}$ & DME & 20 & 37 & - & - \\
\hline 11 & $\mathrm{PhCO}_{2} \mathrm{H}$ & $\mathrm{H}_{2} \mathrm{O}$ & 26 & 96 & 16 & 80 \\
\hline
\end{tabular}

${ }^{a}$ All reactions were performed on a $0.25 \mathrm{mmol}$ scale at room temperature for 2 days. ${ }^{b}$ Yield of isolated product. ${ }^{c}$ Determined by chiral HPLC after reduction to the corresponding alcohol (see below). ${ }^{d}$ Determined by chiral HPLC. ${ }^{e} 5$ days reaction time. ${ }^{f}$ At $0{ }^{\circ} \mathrm{C}$ we obtained under these reaction conditions $1 \mathrm{a}$ in $54 \%$ yield with $95 \%$ ee, at $50{ }^{\circ} \mathrm{C}$ we observe partial decomposition.

The reaction performed well in toluene at room temperature (Table 1, entry 1), yielding the tetrahydrothiophene carbaldehyde 1a in $40 \%$ overall yield in $92 \%$ ee as a single regio- and diastereomer. Spectroscopic experiments revealed that the domino reaction of $(E)-4$-methylpent-2-enal 4a and 2mercapto-1-phenylethanone 5 needs 5 days for completion. It turned out that in the presence of benzoic acid, the reaction time is shorten from 5 to 2 days without any loss of selectivity in 1a, which is obtained now in $56 \%$ yield and $94 \%$ ee as a single isomer (entry 2 ). The screening of different solvents in Table 1 showed that the reaction gave the highest yield and enantioselectivity of the desired product $\mathbf{1}$ in aromatic solvents (entry 2-4). Using $n$-pentane, 1a was formed in a good yield of $63 \%$ over two-steps, but in slightly lower enantioselectivity (entry 5). Decomposition products were detected in polar, aprotic 
solvents, therefore the desired tetrahydrothiophene 1a was obtained in lower yields (entry 6-10). The enantioselectivity of 1a in these solvents was between $10-80 \%$ ee, showing that the conjugate addition of the thiol to the $\alpha, \beta$-unsaturated aldehyde accomplish in a more non-stereoselective way than in nonpolar solvents. Performing the reaction in $\mathrm{H}_{2} \mathrm{O}$ (entry 11) we observe the formation of two regioisomers, the tetrahydrothiophene carbaldehyde $1 \mathrm{a}$ in $26 \%$ yield and $96 \%$ ee, and the (tetrahydrothiophen-2yl)phenyl methanone $\mathbf{2 a}$ in $16 \%$ yield and $80 \%$ ee. Each regioisomer is formed as a single diastereomer. The formation of the second regioisomer will be explained in detail in the mechanistic section. However, avoiding the toxicity of benzene and the harsh conditions to remove $o$-xylene in the crude products we decided to use toluene as solvent for further investigations.

The reaction is very general for different aliphatic $\alpha, \beta$-unsaturated aldehyde bearing different groups (Table 2). Excellent enantioselectivities were obtained for all tetrahydrothiophenes $\mathbf{1 a - h}$ ranging from $90-96 \%$ ee. No other regiosiomer was detected under these reaction conditions, leading to a stereoselective domino reaction of diasteriomerically pure highly functionalized tetrahydrophenes $\mathbf{1}$.

Table 2. Reaction of Thiol 5a with Different $\alpha, \beta$-Unsaturated Aldehydes under Acidic Conditions. ${ }^{a}$

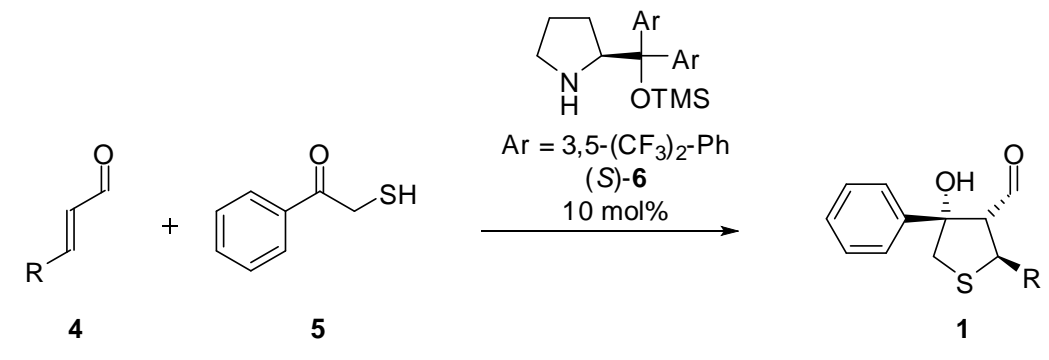

\begin{tabular}{ccccc}
\hline entry & $\mathrm{R}$ & catalyst & $\begin{array}{c}\text { yield } \\
(\%)^{b}\end{array}$ & $\begin{array}{c}\text { ee } \\
(\%)^{c}\end{array}$ \\
\hline 1 & Me $-\mathbf{4 b}$ & $(S)-\mathbf{6}$ & $\mathbf{1 b}-59$ & 90 \\
2 & $\mathrm{Et}-\mathbf{4 c}$ & $(S)-\mathbf{6}$ & $\mathbf{1 c}-73$ & 95 \\
3 & $n-\operatorname{Pr}-\mathbf{4 d}$ & $(S)-\mathbf{6}$ & $\mathbf{1 d}-74$ & 95
\end{tabular}




$\begin{array}{ccccc}4 & i-\mathrm{Pr}-\mathbf{4 a} & (S)-\mathbf{6} & \mathbf{1 a}-56 & 94 \\ 5^{d} & i-\mathrm{Pr}-\mathbf{4 a} & (R)-\mathbf{6} & \text { ent-1a }-51 & -89 \\ 6 & i-\mathrm{Pr}-\mathbf{4 a} & \text { ent-1a }-52 & -2 \\ 7 & n-\mathrm{Bu}-\mathbf{4 e} & \mathbf{1 e}-62 & 90 \\ 8 & n-\mathrm{Hept}-\mathbf{4 f} & (S)-\mathbf{6} & \mathbf{1 f}-44 & 90 \\ 9 & (Z)-n-\mathrm{Hex}-3-\mathrm{en}-\mathbf{4 g} & (S)-\mathbf{6} & \mathbf{1 g}-61 & 93 \\ 10 & \mathrm{CH}_{2} \mathrm{CH}_{2} \mathrm{OTBDMS}-\mathbf{4 h} & (S)-\mathbf{6} & \mathbf{1 h}-44 & 96\end{array}$

\footnotetext{
${ }^{a}$ All reactions were performed on a $0.25 \mathrm{mmol}$ scale in toluene, catalyst $10 \mathrm{~mol} \%$ and $\mathrm{PhCO}_{2} \mathrm{H}$ as additive. ${ }^{b}$ Yields of isolated product. ${ }^{c}$ Determined by chiral HPLC after reduction to the corresponding alcohol (see below). ${ }^{d}$ Contains small amounts of inpurities $(\sim 5 \%)$.
}

Use of the enantiomeric catalyst $(R)-\mathbf{6}$ for the domino reaction of thiol 5a and the $\alpha, \beta$-unsaturated aldehyde 4a afforded the enantiomeric product ent-1a in 51\% yield and with an enantiomeric excess of $89 \%$ ee (Table 2, entry 5). For the Michael-addition step of this domino reaction, the organocatalyst 2[bis(3,5-bistrifluoromethylphenyl)trimethylsilanyloxymethyl]pyrrolidine $\mathbf{6}$ could highlight the fact that this catalyst is very effective in iminium-ion activation of $\alpha, \beta$-unsaturated aldehydes and through a steric shielding of one side of the $\alpha, \beta$-unsaturated aldehyde a high asymmetric induction is obtained. The use of proline as catalyst in this domino reaction gave the product $1 \mathbf{a}$ in $52 \%$ yield as single isomer, but only in $2 \%$ ee (entry 6$)$.

The absolute configuration of the tetrahydrothiophene carbaldehydes $\mathbf{1}$ was confirmed by a singlecrystal X-ray analysis of $\mathbf{1 d}$ (Figure 1). ${ }^{19}$
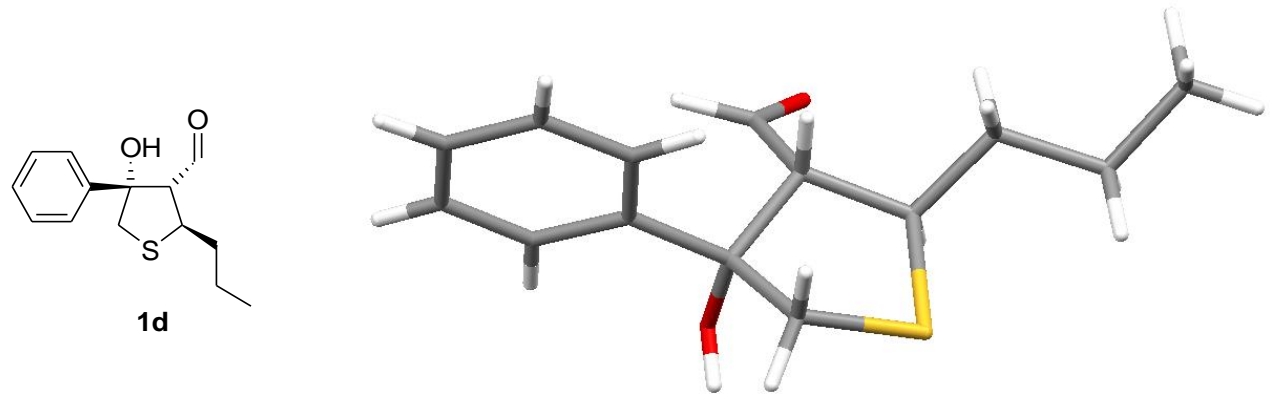
Figure 1. X-ray crystal structure of $(2 R, 3 R, 4 S)$-4-hydroxy-4-phenyl-2-propyltetrahydrothiophene-3carbaldehyde $\mathbf{1 d}$.

Tetrahydrothiophenols are sensitive compounds in regard to oxidation and elimination processes, catalyzed by for $e . g$. acids, leading to aromatic thiophenes. ${ }^{20}$ During our studies we observed no transformation of the tetrahydrothiophenols 1 to the aromatic thiophenes. One reason for the stability of the compounds 1 could be strong intra- or intermolecular hydrogen bondings. The crystal structure of 1d revealed intermolecular hydrogen bonds with a distance of 2.07(0) $\AA$, which might prevent aromatization (Figure 2).

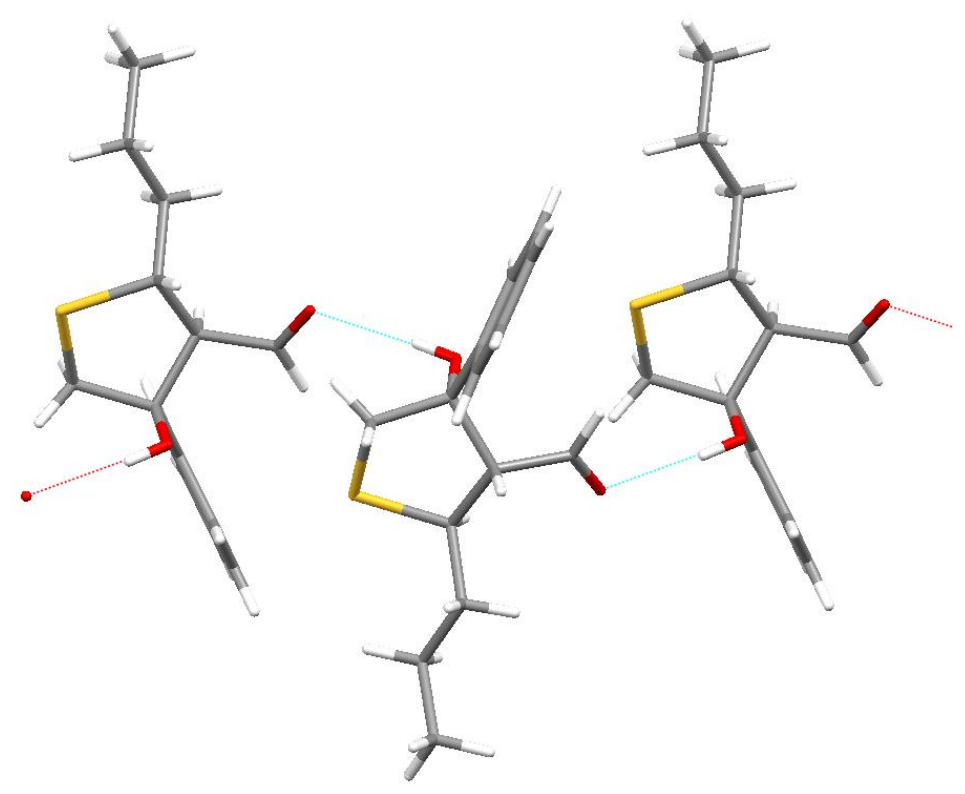

Figure 2. Hydrogen bonds in $(2 R, 3 R, 4 S)-4$-hydroxy-4-phenyl-2-propyltetrahydrothiophene-3carbaldehyde $\mathbf{1 d}$.

We were pleased to find that the tetrahydrothiophene carbaldehydes $\mathbf{1}$ undergo a smooth quantitative reduction to the corresponding alcohols 7 without any racemization (Scheme 2). Even in the presence of $\mathrm{AcOH}$ we observed no elimination reaction leading to the aromatic thiophenes. 
Scheme 2. Reduction of Tetrahydrothiophene Carbaldehydes 1 toTetrahydrothiophen-3-ols 7.

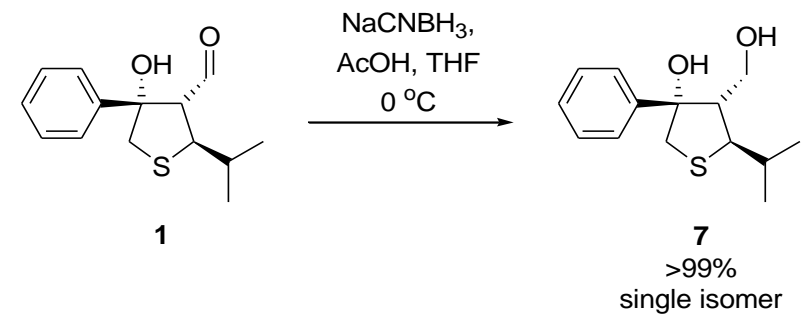

Base-Catalyzed Domino Reactions. The course of the organocatalytic domino mechanism is dependent on small variations in the cyclization reaction step. Temperature and solvent have an influence of yield and enantioselectivity and the additive benzoic acid increase the rate of the domino reaction path to the tetrahydrothiophene carbaldehydes $\mathbf{1}$. Changing the additive benzoic acid to a base, we observed in several cases competing reaction path and the formation of the tetrahydrothiophene 2 (Table 3). Therefore we tested different additives on the conversion and regioselectivity of the domino reaction of (E)-4-methylpent-2-enal 4a with 2-mercapto-1-phenylethanone 5. The results are presented in Table 3.

Table 3. Reaction of (E)-4-Methylpent-2-enal 4a and 2-Mercapto-1-phenylethanone 5 under Basic Conditions. $^{a}$

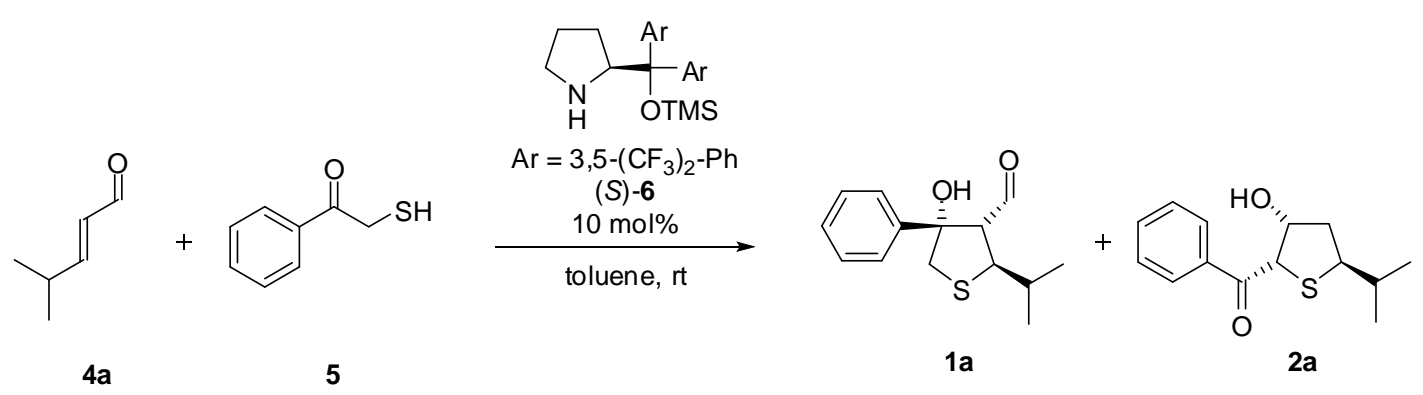

entry additive conversion

$(\%)^{b}$ 1a:2a ee

$(\%)^{c}$ 


\begin{tabular}{ccccc}
\hline 1 & $\mathrm{NaOH}$ & No reaction & - & - \\
2 & $\mathrm{LiOH}$ & 22 & $0: 100$ & nd \\
3 & $\mathrm{Na}_{2} \mathrm{HPO}_{4}$ & 22 & $100: 0$ & nd \\
4 & $\mathrm{NaHCO}_{3}$ & 97 & $2: 98$ & nd \\
5 & $\mathrm{Na}_{2} \mathrm{CO}_{3}$ & 48 & $83: 17$ & nd \\
6 & $\mathrm{Cs}_{2} \mathrm{CO}_{3}$ & 17 & $0: 100$ & nd \\
\hline
\end{tabular}

${ }^{a}$ All reactions were performed on a $0.25 \mathrm{mmol}$ scale in toluene with $10 \mathrm{~mol} \%$ catalyst $(S)-\mathbf{6 a} ;{ }^{b}$ Determined by ${ }^{1} \mathrm{H}$ NMR after $48 \mathrm{~h} ;{ }^{c}$ Determined by chiral HPLC.

No cyclization reaction was observed in the case of $\mathrm{NaOH}$ as additive (Table 3, entry 1). The domino cyclization reaction proceeds to the tetrahydrothiophenes with low conversion using $\mathrm{LiOH}, \mathrm{Na}_{2} \mathrm{HPO}_{4}$, $\mathrm{Na}_{2} \mathrm{CO}_{3}, \mathrm{Cs}_{2} \mathrm{CO}_{3}$ or $\mathrm{Et}_{3} \mathrm{~N}$ (Table 3, entries 2,3,5-7), while applying $\mathrm{NaHCO}_{3}$ as the additive leads in the reaction of $(E)$-4-methylpent-2-enal 4a and 2-mercapto-1-phenylethanone 5 to 97\% conversion (entry 4). The regioselectivity for the latter reaction was determined by ${ }^{1} \mathrm{H}$ NMR spectroscopy to be $98: 2$ in favor to the tetrahydrothiophene 2a. Isolation provided the single diastereoisomere $2 \mathbf{a}$ in $61 \%$ yield and with $80 \%$ ee.

Experiments that probe the scope of the $\alpha, \beta$-unsaturated aldehyde component are summarized in Table 4.

Table 4. Reaction of Thiol 5a with Different $\alpha, \beta$-Unsaturated Aldehydes 4 under Basic Conditions. ${ }^{a}$

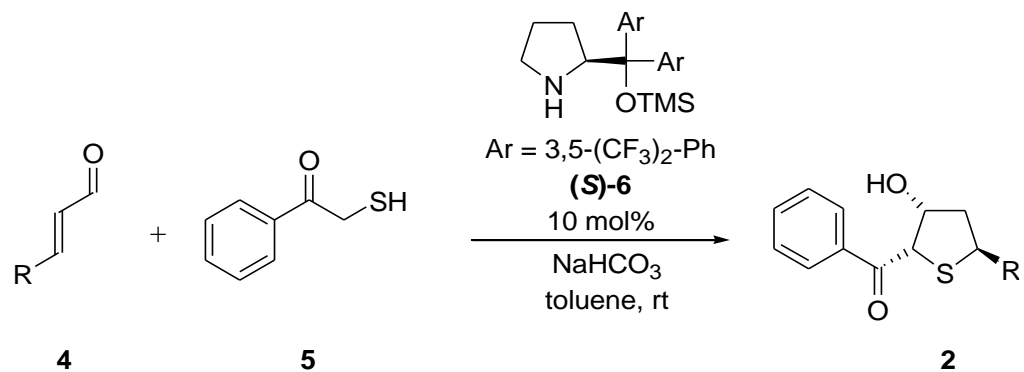




\begin{tabular}{cccc}
\hline entry & $\mathrm{R}$ & $\begin{array}{c}\text { yield } \mathbf{2} \\
(\%)^{b}\end{array}$ & $\begin{array}{c}\text { ee } \\
(\%)^{c}\end{array}$ \\
\hline 1 & $\mathrm{Me}-\mathbf{4 b}$ & $\mathbf{2 b}-59$ & 74 \\
2 & $\mathrm{Et}-\mathbf{4 c}$ & $\mathbf{2 c}-44$ & 72 \\
3 & $n-\mathrm{Pr}-\mathbf{4 d}$ & $\mathbf{2 d}-43$ & 82 \\
4 & $i-\mathrm{Pr}-\mathbf{4 a}$ & $\mathbf{2 a}-61$ & 80 \\
5 & $n$-Bu-4e & $\mathbf{2 e}-66$ & 64 \\
6 & $(\mathrm{Z})-n-\mathrm{Hex}-3-\mathrm{en}-\mathbf{4 g}$ & $\mathbf{2 f}-57$ & 76 \\
7 & $\left(\mathrm{CH}_{2}\right)_{2} \mathrm{OTBDMS}-\mathbf{4 h}$ & $\mathbf{2 g}-61$ & 70 \\
\hline
\end{tabular}

${ }^{a}$ All reactions were performed on a $0.25 \mathrm{mmol}$ scale in toluene, catalyst $10 \mathrm{~mol} \%$ and $\mathrm{NaHCO}_{3}$ as additive. ${ }^{b}$ Yields of isolated product. ${ }^{c}$ Determined by chiral HPLC.

The tetrahydrothiophen-3-ols 2 are formed as a single diastereomer in good yields of $43-66 \%$ yield over two-steps and with $64-82 \%$ ee. The domino process, providing tetrahydrothiophen-3-ols 2 , starts with a Michael-addition of the thiol 5 to the $\alpha, \beta$-unsaturated aldehyde $\mathbf{4}$, as in the asymmetric domino reaction for the formation of 1 . But the ee of the final product $2(64-82 \%$ ee) is lower than the tetrahydrophene carbaldehydes $1(90-95 \%$ ee), derived from the acid-catalyzed domino reaction. Including the result running the reaction in water and with benzoic acid as additive (Table 1, entry 11), it demonstrates the existence of two totally different pathways in the second step, the aldol reaction. One catalytic cycle is probably an asymmetric aldol reaction, catalyzed by $(S)-6$, which leads to an enantioenrichment for the product 1 after the Michael addition, whereby the second catalytic cycle to the formation of 2 is a simple enolization of the Michael adduct by $\mathrm{NaHCO}_{3}$ without further asymmetric induction. Therefore the enantiomeric excess of 2 reflects the asymmetric induction of the Michaeladdition of 5 to the $\alpha, \beta$-unsaturated aldehyde 4 .

An X-ray crystal structure with anomalous diffraction revealed the absolute configuration of $(2 S, 3 R, 5 R)$-(5-ethyl-3-hydroxytetrahydrothiophen-2-yl)phenyl methanone $2 \mathbf{c}$ (Figure 3). ${ }^{21}$ 

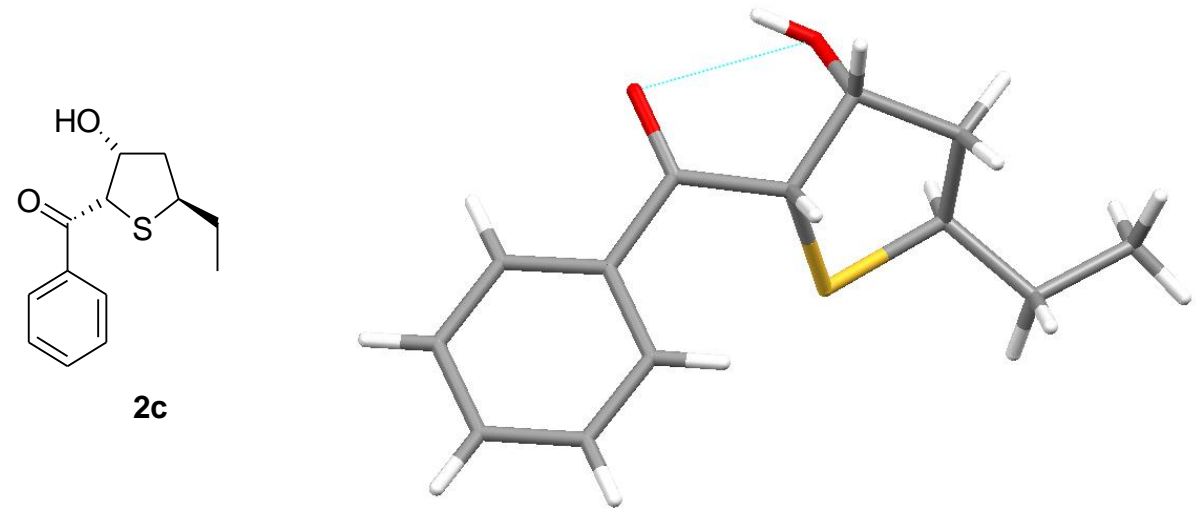

Figure 3. X-ray crystal structure of (2S,3R,5R)-(5-ethyl-3-hydroxytetrahydrothiophen-2-yl)phenyl methanone 2c.

An intramolecular hydrogen bond with a distance of 2.20(0) $\AA$ stabilizes the tetrahydrothiophenes and prevents the elimination of water which would lead to the aromatic compounds.

Mechanistic Insights. The proposed mechanisms for the two domino reactions are summarized in Scheme 3. The Michael addition of the thiol 5 and the $\alpha, \beta$-unsaturated aldehyde 4 follows the known pathway of related organocatalytic transformations. ${ }^{15 \mathrm{~m}, \mathrm{n}, 18 \mathrm{c}, \mathrm{d}, 22}$ The TMS-protected proline derivative (S)-6 generates with the $\alpha, \beta$-unsaturated aldehyde 4 the iminium-ion 8 shielding the $S i$-side of the reactive intermediate. The nucleophilic attack of the thiol $\mathbf{5}$ approaches from the $R e$-side leading to the formation of a $(R)$-configured stereocenter in the enamine 9. The diastereotopic differentiation of the nucleophile is directed from the catalyst yielding a diastereomeric ratio of $\sim 6: 1$. Hydrolysis of the product in aqueous media or in the presence of $\mathrm{NaHCO}_{3}$ releases the catalyst $(S)-\mathbf{6}$ and the thioether 11 which can, after a fast enolization to $\mathbf{1 2}$, react in a diastereospecific aldol reaction to the tetrahydrothiophene $\mathbf{1}$. 
Scheme 3. Mechanism of the Domino Michael-Aldol Reaction for the Formation of Optically Active Tetrahydrothiophenes.
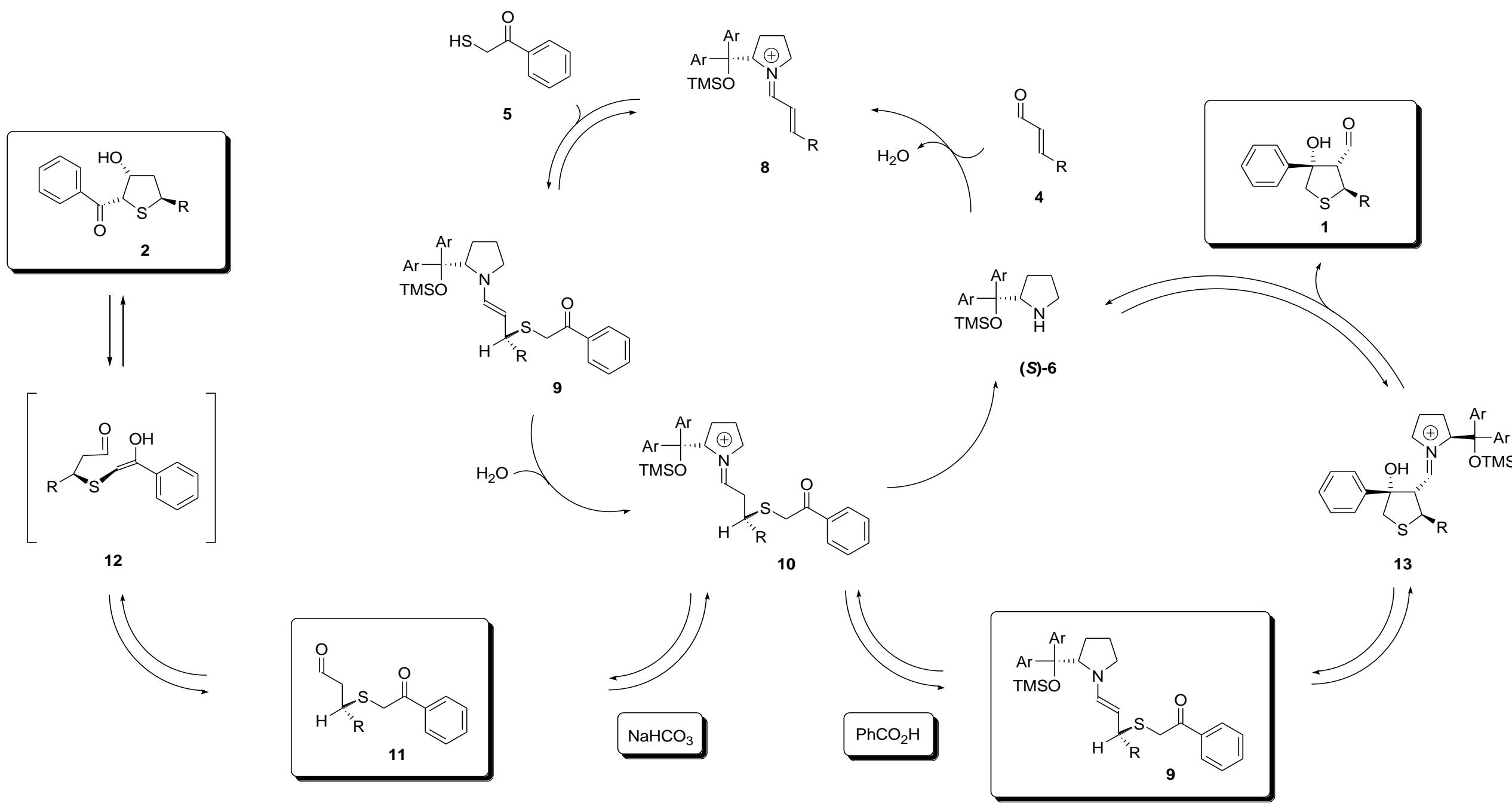

$\mathrm{Ar}=3,5-\left(\mathrm{CF}_{3}\right)_{2}-\mathrm{Ph}$ 
Assuming a thermodynamic controlled $(E)$-enol in the intermediate $\mathbf{1 2}$ with a pseudo-equatorial group $\mathrm{R}$, a hydrogen bonding between the enol and the aldehyde supports the formation of the syn-relationship of the substituents in the product $\mathbf{2}$. The role of $\mathrm{NaHCO}_{3}$ as additive is therefore to promote the hydrolysis and the enolization. No asymmetric induction through the catalyst $(S)-6$ is observed for the second catalytic step in the formation of (tetrahydrothiophen-2-yl)phenyl methanones $\mathbf{2}$.

In the presence of benzoic acid as additive in toluene no hydrolysis to the thioether $\mathbf{1 1}$ takes place. The catalyst remains in the catalytic cycles forming the enamine $\mathbf{8}$ as reactive intermediate. Due to steric hindrance of the chiral substituent in the pyrrolidine ring the enamine $\mathbf{8}$ reacts from an $(E)$-enamine state attacking selectively the carbonyl moiety from the $R e$-side leading to the observed $(2 R, 3 R, 4 S)$-configuration of the tetrahydrothiophenes 1. Hydrolysis of the iminiumion-ion intermediate $\mathbf{1 3}$ gives the diastereomerically pure product $\mathbf{1}$ and sets the catalyst $(S)-\mathbf{6}$ free. The increase of the reaction rate using benzoic acid as an additive can be explained by a possible protonation of the carbonyl group of the intermediate $\mathbf{8}$ forming a more reactive intermediate. Within this mechanistic cascade the catalyst has a multiple asymmetric induction yielding the products 1 with higher enantioenrichment (>90\% ee) than the tetrahydrothiophenes $2\left(70-80 \%\right.$ ee). ${ }^{15 \mathrm{k}}$

\section{Conclusion}

In summary, we have developed new and simple organocatalytic domino reactions for the formation of highly functionalized optically active tetrahydrothiophenes. The catalytic domino reaction can be controlled by the addition of benzoic acid yielding tetrahydrothiophene carbaldehydes 1 in good yields and with excellent enantio- and diastereoselectivity or $\mathrm{NaHCO}_{3}$ giving (tetrahydrothiophen-2-yl)phenyl methanones 2 in moderate yields with very good selectivity. Futhermore we were able to explain the stability of these class of compounds by hydrogen bonding and could show easy, highly efficient transformations of these compounds as a synthetic application. 
Acknowledgement. This work was made possible by a grant from The Danish National Research Foundation. Thanks are expressed to Dr. Jacob Overgaard and Professor Finn Krebs Larsen from the Department of Chemistry, Aarhus University, for performing the X-ray crystal structure analysis.

Supporting Information Available. Complete experimental procedures and characterization. This material is free of charge via the internet at http://pubs.acs.org.

\section{References}

(1) (a) Imwinkelried, R. Chimia 1997, 51, 300. (b) Begley, T. P. Nat. Prod. Rep. 2006, 23, 15. (c) Zempleni, J. Annu. Rev. Nutr. 2005, 25, 175. (d) Ward, T. R. Chem. Eur. J. 2005, 11, 3798. (e) Fernandez-Mejia, C. J. Nutr. Biochem. 2005, 16, 424.

(2) Qiao, C.; Ling, K.-Q.; Shepard, E. M.; Dooley, D. M.; Sayre, L. M. J. Am. Chem. Soc. 2006, 128, 6206 and references therein,

(3) Kato, T.; Tsuzuki, K. Patent Application JP 92-147881, CAN 120:106750

(4) Chorghade, M. S.; Gurjar, M. K.; Palakodety, R. K.; Lalitha, S. V. S.; Sadalapure, K. Adhikari, S. S.; Murugaiah, A. M. S.; Rao, B. V.; Talukdar, A.; Talukdar, A.; Islam, A. Hariprasad, C.; Rao, A. V. R. Patent Application WO 99-US15050, CAN 132:93203

(5) Tsygoanko, V. A.; Blume, Y. B. Bioplim. Kletka 1997, 13, 484.

(6) (a) Mukaiyama, T.; Asanuma, H.; Hachiya, I.; Harada, T.; Kobayashi, S. Chem. Lett. 1991, 7, 1209.

(b) Hauptman, E.; Shapiro, R.; Marshall, W. Organometallics 1998, 17, 4976.

(7) Williams, D. R.; Jass, P. A.; Tse, H. L. A.; Gaston, R. D. J. Am. Chem. Soc. 1990, 112, 4552. 
(a) Higai, S.; Nara, J.; Ohno, T. Surf. Sci. 2006, 600, 685. (b) Sako, E.; Kondoh, H.; Nakai, I.; Nambu, A.; Nakamura, T.; Ohta, T. Chem. Phys. Lett. 2005, 413, 267. (c) Nagamatsu, S.; Kaneto, K.; Azumi, R.; Matsumoto, M.; Yoshida, Y.; Yase, K. J. Phys. Chem B, 2005, 109, 9374. (d) Noh, J.; Ito, E.; Nakajima, K.; Kim, J.; Lee, H.; Hara, M. J. Phys. Chem. B, 2002, 106, 7139. (e) Liu, G.; Rodriguez, J. A.; Dvorak, J.; Hrbek, J. Jirsak, T. Surf. Sci. 2002, 505, 295.

(9) Huang, H.; Yang, X. Colloids Surf. A, Physicochemical and Engineering Aspects, 2005, $255,11$.

(10) (a) Kühnle, A.; Linderoth, T.; Hammer, B.; Besenbacher, F. Nature, 2002, 415, 891. (b) Kühnle, A.; Linderoth, T.; Besenbacher, F. J.Am. Chem. Soc. 2003, 125, 14680.

(11) (a) Ponce, A. M.; Overman, L. E. J. Am. Chem. Soc. 2000, 122, 8672. (b) Desmaële, D.; DelarueCochin, S.; Cavé, C.; d’Angelo, J.; Morgant, G. Org. Lett. 2004, 6, 2421. (c) Popsavin, V.; Beric, O.; Velimirovic, S.; Miljkovic, D. J. Serb. Chem. Soc. 1993, 9, 717. (d) Rao, A. V. R.; Reddy, K. A.; Srinivas, N. R.; Gurjar, M. K.; Padmaja, N.; Ramakumar, S.; Viswamitra, M. A.; Swapna, G. V. T.; Jagannadh, B.; Kunwar, A. C. J. Chem. Soc. Perkin Trans. 1 1993, 1255. (e) Dehmlow, E. V.; Westerheide, R. Synthesis 1992, 10, 947.

(a) Tietze, L. F. Chem. Rev. 1996, 96, 115. (b) Tietze, L. F.; Beifuss, U. Angew. Chem. Int. Ed. Engl. 1993, 32, 131. (c) Simon, C.; Constantieux, T.; Rodriguez, J. Eur. J. Org. Chem. 2004, 4957. (d) Ramon, D. J.; Yus, M. Angew. Chem. Int. Ed. 2005, 44, 1602. (e) Guo, H.; Ma, J. Angew. Chem. Int. Ed. 2006, 45, 354. (f) Pellisier, H. Tetrahedron 2006, 62, 2143. (g) Nicolaou, K. C.; Montagnon, T.; Synder, S. A. Chem. Comm. 2003, 551.

(13) Trost, B. M. Angew. Chem. Int. Ed. Engl. 1995, 34, 259.

(14) Wasilke, J.-C.; Obrey, S. J.; Baker, R. T.; Bazan, G. C. Chem. Rev. 2005, 105, 1001. 
(15) For selected organocatalytic domino reactions involving conjugate additions, see e. g.: (a) Enders, D.; Hüttl, M. R. M.; Grondal, C.; Raabe, G. Nature 2006, 441, 861. (b) Eder, U.; Sauer, G.; Wichert, R. Angew. Chem. 1971, 83, 492. (c) Hajos, Z. G.; Parrish, D. R. J. Org. Chem. 1974, 39, 1615. (d) Zhong, G.; Hoffmann, T.; Lerner, R. A.; Danishefsky; Barbas, C. F., III. J. Am. Chem. Soc. 1997, 119, 8131. (e) List, B.; Lerner, R. A.; Barbas, C. F.; III. Org. Lett. 1999, 1, 59. (f) Bui, T.; Barbas, C. F.; III. Tetrahedron Lett. 2000, 41, 6951. (g) Itoh, T.; Yokoya, M.; Miyauchi, K.; Nagata, K.; Ohsawa, A. Org. Lett. 2003, 5, 4301. (h) Halland, N.; Aburel, P. S.; Jørgensen, K. A. Angew. Chem. Int. Ed. 2004, 43, 1272. (i) Pukkinen, J.; Aburel, P. S.; Halland, N.; Jørgensen, K. A. Adv. Synth. Catal. 2004, 346, 1077. (j) Yamamoto, Y.; Momiyama, N.; Yamamoto, H. J. Am. Chem. Soc. 2004, 126, 5962. (k) Huang, Y.; Walji, A.; Larsen, C. H.; MacMillan, D. W. C. J. Am. Chem. Soc. 2005, 127, 15051. (1) Yang, J. W.; Hechavarria Fonseca, M. T.; List, B. J. Am. Chem. Soc. 2005, 127, 15036. (m) Marigo, M.; Bertelsen, S.; Landa, A.; Jørgensen, K. A. J. Am. Chem. Soc. 2006, 128, 5475. (n) Marigo, M.; Schulte, T.; Franzén, J.; Jørgensen, K. A. J. Am. Chem. Soc. 2005, 127, 15710. (o) Sundén, H.; Ibrahem, I.; Erikson, L.; Córdova, A. Angew. Chem. Int. Ed. 2005, 44, 4877 .

(16) For recent reviews on organocatalysis see: (a) Dalko, P. L.; Moisan, L. Angew. Chem. Int. Ed. 2004, 43, 5138. (b) Berkessel, A.; Gröger, H. Asymmetric Organocatalysis; VCH: Weinheim, Germany, 2004. (c) Seayed, J.; List, B. Org. Biomol. Chem. 2005, 3, 719. (d) Acc. Chem. Res. 2004, 37 (8), special issue on organocatalysis.

(17) For some recent feature articles of enamine- and imine-catalysis, see e. g.: (a) List, B. Chem. Comm. 2006, 819. (b) Marigo, M.; Jørgensen, K. A. Chem. Comm. 2006, 2001. For application of enamine-catalysis in Michael additions, see e. g.: (c) Chi, Y.; Gellman, S. H. Org. Lett. 2005, 7, 4253. (d) Peelen, T. J.; Chi, Y.; Gellman, S. H. J. Am. Chem. Soc. 2005, 127, 11598. (e) Cao, C.L.; Ye, M.-C.; Sun, X.-L.; Tang, Y. Org. Lett. 2006, 8, 2901. (f) Zu, L.; Wang, J.; Li, H.; Wang, 
W. Org. Lett. 2006, 8, 3077. (g) Luo, S.; Mi, X.; Zhang, L.; Liu, S.; Xu, H.; Cheng, J.-P. Angew.

Chem. Int. Ed. 2006, 45, 3093. (h) Huang, H.; Jacobsen, E. N. J. Am. Chem. Soc. 2006, 128, 7170.

(i) Mase, N.; Watanabe, K.; Yoda, H.; Takabe, K.; Tanaka, F.; Barbas, C. F. III J. Am. Chem. Soc.

2006, 128, 4966. For application of enamine-catalysis in Mannich reactions, see e. g.: (j)

Mitsumori, S.; Zhang, H.; Cheong, P. H.-Y.; Houk, K. N.; Tanaka, F.; and Barbas, C. F. III J. Am.

Chem. Soc. 2006, 128, 1040. (k) Kano, T.; Yamaguchi, Y.; Tokuda, O.; Maruoka, K. J. Am. Chem.

Soc. 2005, 127, 16408. (1) List, B. J. Am. Chem. Soc. 2000, 122, 9336. For application of enamine-

catalysis in fluorinations, see e. g.: (m) Enders, D.; Hüttl, M. R. M. Synlett. 2005, 991. (n) Marigo, M.; Wabnitz, T. C.; Fielenbach, D.; Braunton, A.; Kjærsgaard, A.; Jørgensen, K. A. Angew. Chem. Int. Ed. 2005, 44, 3703. (o) Steiner, D. D.; Mase, N.; Barbas, C. F. III Angew. Chem. Int. Ed. 2005, 44, 3706. (p) Beeson, T. D.; MacMillan, D. W. C. J. Am. Chem. Soc. 2005, 127, 8826. (q) Brandes, S.; Niess, B.; Bella, M.; Prieto, A.; Overgaard, J.; Jørgensen, K. A. Chem. Eur. J. 2006, 12, 6039. For application of enamine-catalysis in chlorinations, see e. g.: (r) Brochu, M. P.; Brown, S. P.; MacMillan, D. W. C. J. Am. Chem. Soc. 2004, 126, 4108. (s) Halland, N.; Braunton, A.; Bachmann, S.; Marigo. M.; Jørgensen, K. A. J. Am. Chem. Soc. 2004, 126, 4790. (t) Halland, N.; Lie, M. A.; Kjærsgaard, A.; Marigo, M.; Schiøtt, B.; Jørgensen, K. A. Chem. Eur. J. 2005, 11, 7083. (u) Marigo, M.; Bachmann, S.; Halland, N.; Braunton, A.; Jørgensen, K. A. Angew. Chem. Int. Ed. 2004, 43, 5507. For application of enamine-catalysis in brominations, see e. g.: (v) Bertelsen, S.; Halland, N.; Bachmann, S.; Marigo, M.; Braunton, A.; Jørgensen, K. A. Chem. Comm. 2005, 4821. For application of enamine-catalysis in sulfenylations, see e. g.: (x) Wang, J.; Li, H.; Mei, Y.; Lou, B.; Xu, D.; Xie, D.; Gou, H. Wang, W. J. Org. Chem. 2005, 70, 5678. (y) Marigo, M.; Wabnitz, T. C.; Fielenbach, D.; Jørgensen, K. A. Angew. Chem. Int. Ed. 2005, 44, 794. For application of enamine-catalysis in oxygenations, see e. g.: (z) Zhong, G.; Angew. Chem. Int. Ed. 2003, 42, 4247. (aa) Brown, S. P.; Brochu, M. P.; Sinz C. J.; MacMillan, D. W. C. J. Am. Chem. Soc. 2003, 125, 10808. (ab) Hayashi, Y.; Yamaguchi, J.; Hibino K.; Shoji, M. Tetrahedron 
Lett. 2003, 44, 8293. (ac) Kumarn, S.; Shaw, D. M.; Longbottom D. A.; Ley, S. V. Org. Lett. 2005, 7, 4189. (ad) Cordova, A.; Sunden, H.; Enqvist, M.; Ibrahem I.; Casas, J. J. Am. Chem. Soc. 2004, 126, 8914. (ae) Mathew, S. P.; Iwamura, H.; Blackmond, D. G. Angew. Chem. Int. Ed. 2004, 43, 3317. For application of enamine-catalysis in hydroxyaminations, see e. g.: (af) Kano, T.; Ueda, M.; Takai, J.; Maruoka, K. J. Am. Chem. Soc. 2006, 128, 6046. For application of enaminecatalysis in alkylations, see e. g.: (ag) Vignola, N.; List, B. J. Am. Chem. Soc. 2004, 126, 450. For applications of iminium-ion catalysis in cycloadditions, see e. g.: (ah) Kunz, R. K.; MacMillan, D. W. C. J. Am. Chem. Soc. 2005, 127, 3240. (ai) Wilson, R. M.; Jen, W. S.; MacMillan, D. W. C. J. Am. Chem. Soc. 2005, 127, 11616. For applications of iminium-ion catalysis in reductions, see $e$. g.: (aj) Ouellet, S. G.; Tuttle, J. B.; MacMillan, D. W. C. J. Am. Chem. Soc. 2005, 127, 32. For applications of iminium-ion catalysis in Mukaiyama-Michael reactions, see $e . g$. (ak) Brown, S. P.; Goodwin, N. C.; MacMillan, D. W. C. J. Am. Chem. Soc. 2003, 125, 1192. For applications of iminium-ion catalysis in Michael reactions, see e. g.: (al) Prieto, A.; Halland, N.; Jørgensen, K. A. Org. Lett. 2005, 7, 3897. (am) Halland, N.; Hansen, T.; Jørgensen, K. A. Angew. Chem. Int. Ed. 2003, 42, 4955. (an) Knudsen, K. R.; Mitchell, C. E. T.; Ley, S. V. Chem. Commun. 2006, 66 and references therein.

(a) Wilde, R. G.; Billheimer, J. T.; Germain, S. J.; Hausner, E. A.; Meunier, P. C.; Munzer, D. A.; Stoltenberg, J. K.; Gillies, P. J.; Burcham, D. L.; Huang, S.-M.; Klaczkiewicz, J. D.; Ko, S. S., Wexler, R. R. Bioorg. Med. Chem. 1996, 4, 1493. (b) Vedejs, F.; Eberlein, T. H.; Varic, D. L. J. Am. Chem. Soc. 1982, 104, 1445. (c) Vedejs, F.; Eberlein, T. H.; Mazur, D. J.; McClure, C.; Perry, D. A.; Ruggeri, R.; Schwartz, E.; Stults, J. S.; Varie, D. L.; Wilde, R. G.; Wittenberger, S. J. Org. Chem. 1986, 51, 1556.

(19) Recent examples using catalyst 6 see e. g.: (a) Brandau, S.; Landa, A.; Franzén, J.; Marigo, M. Jørgensen, K. A. Angew. Chem. Int. Ed. 2006, 45, 4305. (b) Marigo, M.; Fránzen, J.; Poulsen, T. 
B.; Zhuang, W.; Jørgensen, K. A. J. Am. Chem. Soc. 2005, 127, 6964. For application of 2a in enamine catalyzed reactions, see: (c) Fránzen, J.; Marigo, M.; Fielenbach, D.; Wabnitz, T. C.; Kjærsgaard, A.; Jørgensen, K. A. J. Am. Chem. Soc. 2005, 127, 18296. (d) Marigo, M.; Wabnitz, T. C.; Fielenbach, D.; Jørgensen, K. A. Angew. Chem. Int. Ed. 2005, 44, 794. (e) Hayashi, Y.; Gotoh, H.; Hayashi, T.; Shoji, M. Angew. Chem. Int. Ed. 2005, 44, 4212. (f) Chi, Y.; Gellman, S. H. J. Am. Chem. Soc. 2006, 128, 6804. (g) Ibrahem, I.; Zhao, G.-L.; Sundén, H.; Córdova, A. Tetrahedron Lett. 2006, 47, 4659.

(20) X-ray crystal structure analysis of 1d: Formula $\mathrm{C}_{14} \mathrm{H}_{18} \mathrm{O}_{2} \mathrm{~S}$, weight $250.36 \mathrm{~g} \mathrm{~mol}^{-1}$. See Supporting Information.

(21) (a) Fevig, T. L.; Philips, W. G.; Lau, P. H. J. Org. Chem. 2001, 66, 2493. (b) Kaneko, H.; Yamato, Y.; Kurokawa, M. Chem. Pharm. Bull. 1968, 16, 1200. (c) Nehlsen, J.; Benzinger, J.; Kevrekidis, I. Ind. Eng. Chem. Res. 2006, 45, 518. (d) Pocar, D.; Rossi, L. M.; Stradi, R.; Trimarco, P. J. Chem. Soc., Perkin Trans. I, 1977, 2337.

(22) X-ray crystal structure analysis of $2 \mathrm{c}$ : Formula $\mathrm{C}_{13} \mathrm{H}_{16} \mathrm{O}_{2} \mathrm{~S}$, weight $236.33 \mathrm{~g} \mathrm{~mol}^{-1}$. See Supporting information.

(23) Zhuang, W.; Marigo, M.; Jørgensen, K. A. Org. Biomol. Chem. 2005, 21, 3883. 


\section{Graphical Abstract}

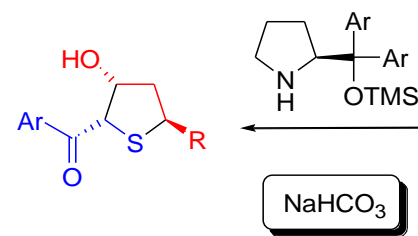

single regioand diastereomer $64-82 \%$ ee

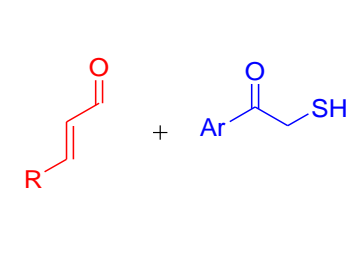

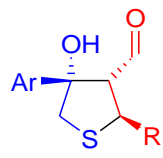

single regioand diastereomer 90-96\% ee 